\title{
NOTES
}

\section{NOTES ON THE BREEDING BIOLOGY OF THE HOODED GROSBEAK (COCCOTHRAUSTES ABEILLEI)}

RICHARD A. ERICKSON, San Diego Natural History Museum, P.O. Box 121390, San Diego, California 92112; richard.erickson@lsa.net

RENÉ VALDÉS, 55-A 189a Francisco de Montejo, C.P. 97203, Mérida, Yucatan, México; guacamayero@gmail.com

The Hooded Grosbeak (Coccothraustes abeillei) is endemic to evergreen montane forests from northern Mexico to northern Central America (Carter 2014). Like its two congeners-the Hawfinch (C. coccothraustes) of Europe, Asia, and north Africa, and the Evening Grosbeak (C. vespertinus) of North America-the Hooded Grosbeak is generally quiet and inconspicuous when nesting (Komar 2002). Nearly 75 years passed between the formal naming of the Evening Grosbeak and the first descriptions of its nesting habits (Speirs 1968). Clement (2010) and Carter (2014) summarized what very little has been published concerning nesting of the Hooded Grosbeak, primarily on the basis of the work of Thurber et al. (1987; phenology), Howell and Webb (1995; brief description of nest site), and Komar (2002; phenology, nest description, and behavior). Carter (2014) noted further that "data on clutch size, egg color, and incubation have not been recorded." Additional references to the timing and locations for "breeding" and juveniles collected were listed by Miller et al. (1957). We prepared this note in response to this paucity of information.

On 21 June 2021 Mario Álvarez Lara and Kurt and Cindy Radamaker accompanied us in searching for Hooded Grosbeaks and other mysteries at Valle del Ovni $\left(23^{\circ}\right.$ $03^{\prime} 20^{\prime \prime} \mathrm{N}, 99^{\circ} 13^{\prime} 46^{\prime \prime} \mathrm{W}$; elevation 1360 m), Gómez Farías Municipality, Tamaulipas, Mexico. At approximately 13:30 Álvarez Lara spotted a male Hooded Grosbeak. The bird soon flew a short distance across the road on which we were standing to join a female. While the rest of us were admiring the pair of adults, Álvarez Lara found two live young birds (Figure 1) on the road at our feet. We eventually looked up to see the nest as well, about $3 \mathrm{~m}$ from where the adults had been before slipping away while we were distracted with the young. Valdés found no grosbeaks in the area during a return visit on 9 July 2021.

The nest was approximately $4 \mathrm{~m}$ above the ground on the horizontal branch of a large Mexican Hornbeam (Carpinus tropicalis) in a tangle with grape (Vitis sp.) (Figures 2 and 3). We were unable to see the top of the nest, including its contents, but from below it appeared to be a rather flat, bulky platform of twigs, perhaps 20 $\mathrm{cm}$ in diameter. In all of these ways the nest fit well within the range of characteristics described previously for the Hooded Grosbeak (Carter 2014), as well as for the Hawfinch (Cramp and Perrins 1994) and Evening Grosbeak (Speirs 1968, Gillihan and Byers 2001).

The nestlings were perhaps 8-10 days old-on the basis of nestling Evening Grosbeaks opening their eyes at an age of 4-6 days and fledging at 13-14 days (Gillihan and Byers 2001) - too young to be out of the nest. The birds were undergoing prejuvenal molt, as evidenced by the synchronous growth of coverts and remiges, as well as the loose down feathers being replaced (R. S. Terrill pers. comm.). Feathers of the breast were cinnamon colored, those of the back olive, and those of the wings primarily blackish (with pale tertials just emerging and underwing coverts apparently pale yellow). Only pale gray down feathers were present on the head, and down feathers were also scattered on the back and wings. The nestlings' bills were 


\section{NOTES}

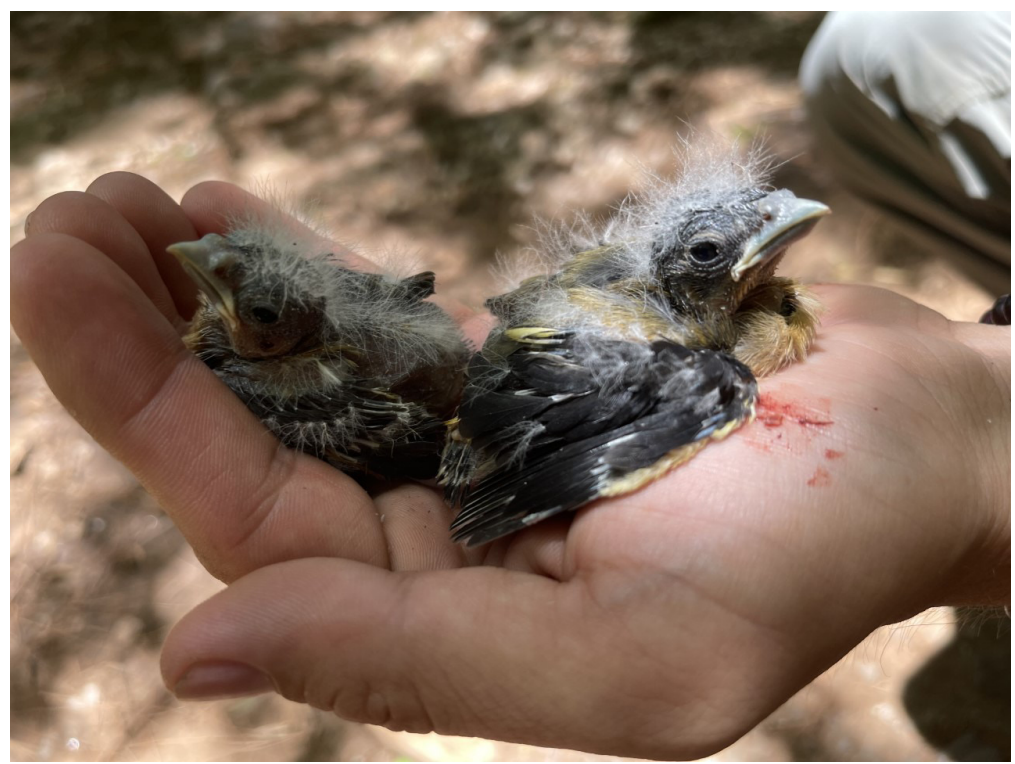

Figure 1. Young Hooded Grosbeaks found below their nest at Valle del Ovni, Tamaulipas, Mexico, 21 June 2021.

Photo by Richard A. Erickson

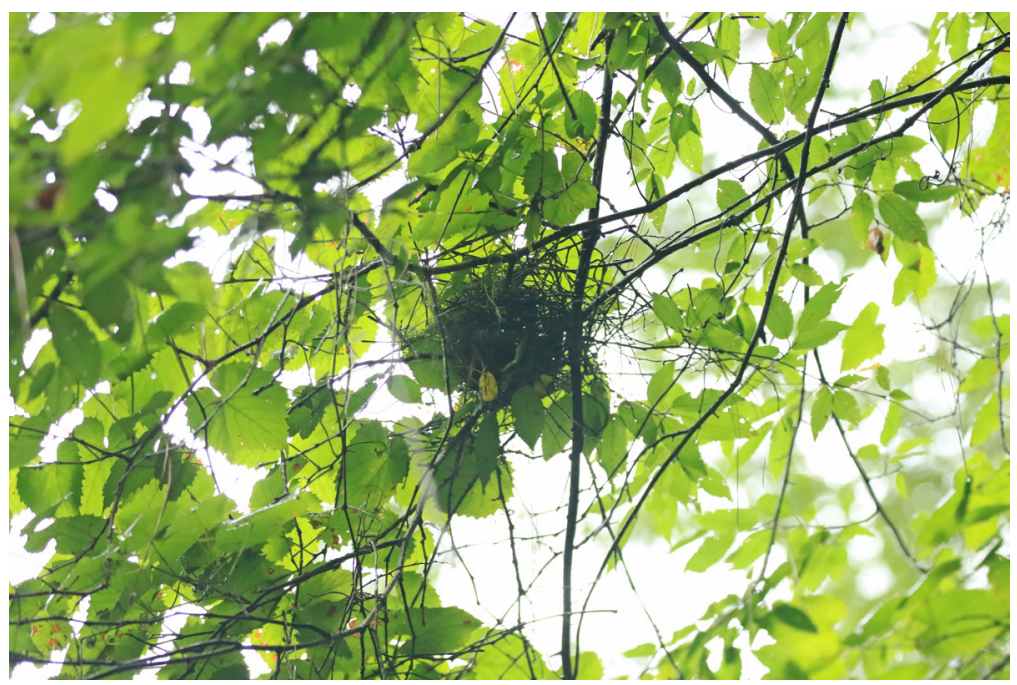

Figure 2. View from below of nest of the Hooded Grosbeak in a tangle of Mexican Hornbeam (Carpinus tropicalis) and grape (Vitis sp.) at Valle del Ovni, Tamaulipas, Mexico, 9 July 2021. 


\section{NOTES}

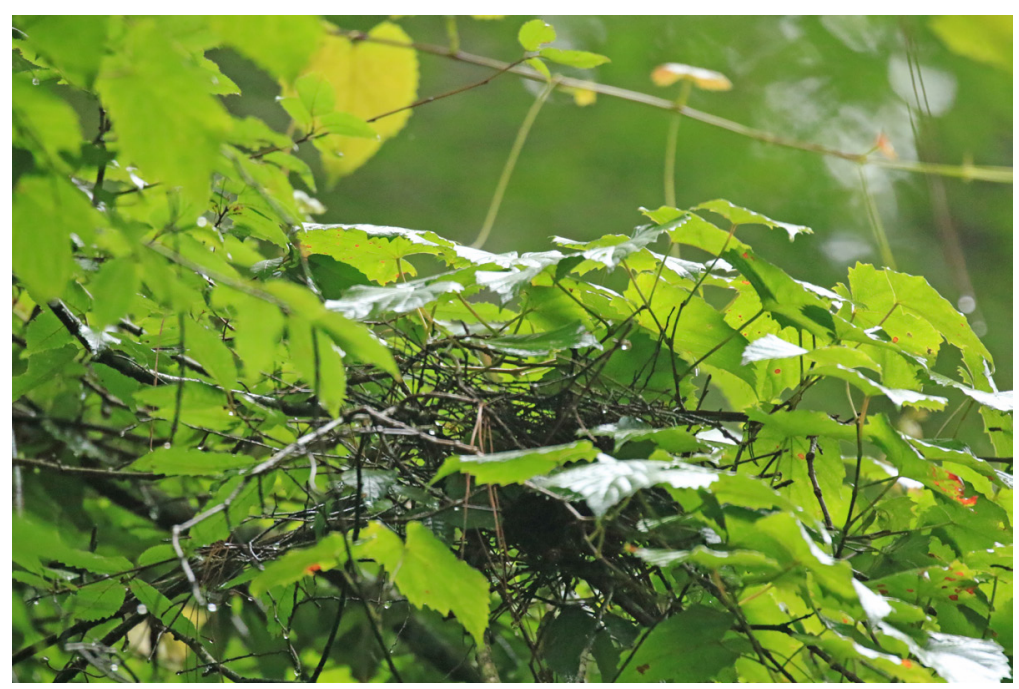

Figure 3. Close-up view of Hooded Grosbeak (Coccothraustes abeillei) nest at Valle del Ovni, Tamaulipas, Mexico, 9 July 2021.

Photo by René Valdés

drab gray-green, and their legs and feet were pale pinkish. Their eyes were blackish. Nestlings of the species have not been described or photographed previously.

The larger of the two nestlings was bloody. We have no idea what befell them or what portion of the clutch they may have represented. In the Hawfinch the clutch size ranges from 3 to 5 (Cramp and Perrins 1994), in the Evening Grosbeak 2 to 5 (Gillihan and Byers 2001). The nestlings' different sizes suggest asynchronous hatching, as is reported for the Hawfinch (Cramp and Perrins 1994). We left the young together on the slope next to the road, their fate unknown. Additional photos are posted at https://ebird.org/checklist/S90631344.

We searched the literature and examined all reports of the Hooded Grosbeak through https://ebird.org for references to potential nesting (Table 1). Evidence of nesting in eBird extended from 8 April to 11 October and covered the length of the species' range from Chihuahua to El Salvador (Table 1). Nest substrates mentioned include pine $(n=2)$ and Mexican Cypress (Cupressus lusitanica; $n=1)$. The most interesting observations are from San Cristobal de las Casas, Chiapas, where Francesca Albini observed family groups as late as September in 2013 and 2017. In 2017 adults were building a nest from 27 August to 1 September, overlapping with the time that young were begging from the same individuals, from 27 August to 2 September (https://ebird.org/checklist/S38859177, S38919551, S38949309, and S38967506). This strongly suggests attempted double brooding, but the second attempt appears to have ultimately failed. Komar (2002) also suspected renesting in El Salvador 27-29 July 1999. Cramp and Perrins (1994) reported multiple broods of the Hawfinch in captivity but no confirmation in the wild. Double brooding is rare in the Evening Grosbeak but has apparently been confirmed in Colorado (Gillihan and Byers 2001). The long nesting season for the Hooded Grosbeak documented here suggests that multiple broods may not be unusual, or that the phenology of its food varies regionally and/or by year. 
TABLE 1 Phenology of Nesting of the Hooded Grosbeak

\begin{tabular}{|c|c|c|c|c|c|c|}
\hline \multirow[b]{3}{*}{ Location } & \multicolumn{6}{|c|}{ Source } \\
\hline & \multirow[b]{2}{*}{$\begin{array}{l}\text { Published } \\
\text { literature }^{a}\end{array}$} & \multicolumn{5}{|c|}{ eBird $^{b}$} \\
\hline & & $\begin{array}{l}\text { Visiting } \\
\text { probable } \\
\text { nest site }\end{array}$ & $\begin{array}{c}\text { Nest building/ } \\
\text { carrying nest } \\
\text { material }\end{array}$ & $\begin{array}{c}\text { Occupied } \\
\text { nest }\end{array}$ & $\begin{array}{l}\text { Recently } \\
\text { fledged } \\
\text { young }\end{array}$ & $\begin{array}{l}\text { Feeding } \\
\text { young }\end{array}$ \\
\hline Chihuahua & & & & & & $\begin{array}{l}14 \text { Aug } \\
(n=1)\end{array}$ \\
\hline Sinaloa & $\begin{array}{c}19 \text { Jun-29 Jul } \\
(n=1)\end{array}$ & & & & & \\
\hline Durango & $\begin{array}{l}28 \text { Jun } \\
(n=1)\end{array}$ & & & & & \\
\hline Tamaulipas & $\begin{array}{c}8 \text { Jun (juvenile; } \\
n=1 \text { ) }\end{array}$ & & & & & \\
\hline Hidalgo & & & $\begin{array}{l}22 \mathrm{Apr} \\
(n=1)\end{array}$ & & & \\
\hline Michoacán & $\begin{array}{c}30 \text { Jun } \\
\text { (small juvenile; } \\
n=1 \text { ) }\end{array}$ & & & & & \\
\hline Distrito Federal & & & $\begin{array}{l}11 \text { Apr } \\
(n=1)\end{array}$ & & & \\
\hline Morelos & $\begin{array}{c}8 \mathrm{Mar} \\
(n=1)\end{array}$ & & & & & \\
\hline Guerrero & $\begin{array}{l}3 \text { Jun (laying) } \\
-16 \text { Jun }(n=2)\end{array}$ & & & & & \\
\hline Chiapas & $\begin{array}{c}30 \text { May-7 Jun } \\
(n=1)\end{array}$ & & $\begin{array}{c}8 \text { Apr-1 Sep } \\
(n=6)\end{array}$ & & $\begin{array}{c}30 \text { Jul-1 } \\
\text { Sep } \\
(n=3)\end{array}$ & \\
\hline Guatemala & & $\begin{array}{l}15 \text { Jun } \\
(n=1)\end{array}$ & $\begin{array}{c}13 \text { Apr-30 Aug } \\
(n=8)\end{array}$ & $\begin{array}{l}7 \text { May } \\
(n=1)\end{array}$ & $\begin{array}{l}17 \mathrm{Jul} \\
(n=1)\end{array}$ & $\begin{array}{c}21 \text { Aug-11 } \\
\text { Oct } \\
(n=2)\end{array}$ \\
\hline El Salvador & $\begin{array}{c}\text { May } \\
\text { (copulation; } \\
n=1 \text { ) }\end{array}$ & & $\begin{array}{c}23 \text { Jun-29 Jul } \\
(n=2)\end{array}$ & & $\begin{array}{l}24 \text { Jun } \\
(n=1)\end{array}$ & \\
\hline $\begin{array}{l}\text { Full range } \\
(n=37)\end{array}$ & $\begin{array}{c}8 \mathrm{Mar}-29 \mathrm{Jul} \\
(n=9)\end{array}$ & $\begin{array}{l}15 \text { Jun } \\
(n=1)\end{array}$ & $\begin{array}{c}8 \text { Apr-1 Sep } \\
(n=18)\end{array}$ & $\begin{array}{l}7 \text { May } \\
(n=1)\end{array}$ & $\begin{array}{l}24 \text { Jun- } \\
1 \text { Sep } \\
(n=5)\end{array}$ & $\begin{array}{l}14 \text { Aug- } \\
11 \text { Oct } \\
(n=3)\end{array}$ \\
\hline
\end{tabular}

${ }^{a}$ Based on eight reports from Miller et al. (1957) from Mexico (described only as "breeding" unless otherwise specified) and one from Thurber et al. (1987) from El Salvador.

${ }^{b}$ Based on information included in 28 eBird checklists (some linked to additional observer checklists for the same time and place) describing reproduction in the Hooded Grosbeak, of the 6335 reporting the species from 1999 through June 2021: Mexico 2817, Guatemala 3443, Honduras 4, El Salvador 71.

We thank Mario Álvarez Lara and Kurt and Cindy Radamaker for assistance in the field, and José Alberto Lobato García, Esteban Berrones Benítez, Robert A. Hamilton, and Weston G. Burt for advice, assistance, and inspiration. Marshall J. Iliff provided easy access to eBird observations, and Ryan S. Terrill helped with examination of specimens at the Moore Laboratory of Ornithology, Occidental College, Los Angeles. We also used the database of specimen collections at http://www.vertnet. org. Matthew J. Baumann, Oliver Komar, Philip Unitt, and an anonymous reviewer formally commented on the manuscript. 


\section{NOTES}

\section{LITERATURE CITED}

Carter, A. 2014. Hooded Grosbeak (Coccothraustes abeillei), version 1.0, in Neotropical Birds Online (T. S. Schulenberg, ed.). Cornell Lab Ornithol., Ithaca, NY; doi. org/10.2173/bow.hoogro1.01.

Clement, P. 2010. Fringillidae, in Handbook of the Birds of the World (J. del Hoyo, A. Elliott, and D. A. Christie, eds.), vol. 15, pp. 512-617. Lynx Edicions, Barcelona.

Cramp, S., and Perrins, C. M. (eds.). 1994. The Birds of the Western Palearctic, vol. 8. Oxford Univ. Press, Oxford, England.

Gillihan, S. W., and Byers, B. E. 2001. Evening Grosbeak (Coccothraustes vespertinus), in The Birds of North America (A. F. Poole and F. B. Gill, eds.), no. 599. Birds N. Am., Inc., Philadelphia; https://doi.org/10.2173/bow.evegro.01.

Howell, S. N. G., and Webb, S. 1995. A Guide to the Birds of Mexico and Northern Central America. Oxford Univ. Press, Oxford, England.

Komar, O. 2002. Birds of Montecristo National Park, El Salvador. Ornitología Neotropical 13:167-193.

Miller, A. H., Friedmann, H., Griscom, L., and Moore, R. T. 1957. Distributional check-list of the birds of Mexico, part II. Pac. Coast Avifauna 33.

Speirs, D. H. 1968. Hesperiphona vespertina, Evening Grosbeak, in Life histories of North American cardinals, grosbeaks, buntings, towhees, finches, sparrows, and allies (O. L. Austin, Jr., ed.), part 1. U. S. Natl. Bull. 237:206-256; https:// doi.org/10.5479/si.03629236.237.1.

Thurber, W. A., Serrano, J. F., Sermeño, A., and Benitez, M. 1987. Status of uncommon and previously unreported birds of El Salvador. Proc. W. Found. Vert. Zool. 3:111-293.

Accepted 1 November 2021

Associate editor: Matthew J. Baumann 